\title{
Lautaro Yankas
}

\section{Responso a Gabriela Mistral}

\section{PEDAGOGIA Y DIPLOMACIA}

\begin{abstract}
7. 180 , el séptimo día de abril y su niñez tiene 4. 3 ynales humildes. Vientos errabundos sacuden su ho2. Gabriela. Un sentido de expresión poética rompe su timidez y hay fuerza humana en surgente caudal. Tiene catorce años y sus versos se publican en periódicos locales. Es maestra un año después y su apostolado empieza en una aldea próxima a Vicuña, su pueblo natal. Obtiene título de maestra primaria en Santiago en 1910 y desde este momento encamina su misión por pueblos y ciudades dei país y del extranjero: en 1911, profesora en el Liceo de Traiguén; en 1912, profesora de Historia en el Liceo de Antofagasta y luego de Castellano en Los Andes; directora del Liceo de Magallanes, en 1918; del Liceo de Temuco, en 1920; del Liceo N. ${ }^{\circ}$ 6, de Santiago, en 1921; comisionada por el gobierno de México en 1922, para reorganizar la educación de aquel país; en 1924 viaja a Europa y a su regreso visita Norteamérica; en 1925 visita Latinoamérica y en ese mismo año el gobierno de Chile le otorga su jubilación de maestra; en 1926 se la distingue con el nombramiento de Secretaria de la sección de la Liga de las Naciones; en 1927 y 1928 representa a Chile en Congresos de Educación en Locarno y Madrid y a la So-
\end{abstract}


ciedad de las Naciones en Roma; en 1930 es invitada a Estados Unidos; en 1931 conoce a Centroamérica y Antillas; en 1932 se la envía a Nápoles como Cónsul y al año siguiente se la nombra en Madrid; viaja por Sudamérica en 1938. Tres años después la encontramos como Cónsul de Chile en Brasil, donde la sorprende el 15 de noviembre de 1945 en que su genio poético conquista para Chile e Indoamérica la máxima gloria del espíritu, el Premio Nobel de Literatura.

\section{SU DRAMA}

Iniciada la adolescencia, conoce la exaltación del amor. El destino se llama Romelio Ureta, modesto empleado de Ferrocarriles. Ella tiene veinte años cuando se suicida el amado. Muere el padre de Gabriela en 1915 y su madre en 1929. La poetisa abreva la entraña herida en los veneros de la Biblia -el Eclesiastés, David, Salomón, los Profetas, el Apocalipsis- y su dolor de criolla herida en el umbral de la ternura se eleva y sublima sin merma de su pulso embravecido.

\section{SU GLORIA}

Los Juegos Florales de Santiago premian sus Sonetos de la Muerte, en 1914. Se publica en México Loctura para Mujeres, en 1922, y en 1923 en Nueva York el Instituto de las Españas ofrece la primera edición de Desolación. En 1924, da en España otro volumen, Ternura. En 1926, en Argentina, se publica la tercera edición de Desolación. En 1924, en España, da Nubes Blancas y Breve Descripción de Chile. En 1938, aparece Tala, en Buenos Aires. En 1945, el Premio Nobel de Literatura la encuentra repechando los caminos del alma atribulada y crecida, y acercándose a su voz más pura. Ya se anuncia un nuevo libro, Lagar. 
Desde el año profético de Los Sonetos de la Muerte, el misterio de una poesía nueva se ha vaciado sobre los ríos de América bárbara y ha engendrado en sus tierras para ir luego por los caminos del planeta borrando países, desgajando vanidades, en voluntad de redención de conciencias y salvación de la Belleza amenazada. ¿Porqué había de brotar en la cobriza tierra de Chile, sobre el flanco herido de esta América, el labio bíblico que diría la verdad viviente y eterna, escondida hasta ayer en los repliegues de un mundo cansado? Porque así ha sido siempre sobre la tierra, cuando los tiempos se tienden a dormir su agobio y se deshacen en migajas con sus sueños sin sangre. Los paganismos pidieron toda la pasión a los pueblos y se levantaron ardiendo en gloria y esperanza sobre un mundo sumergido en la crueldad de sus dioses. Después, encima de los Césares, la nueva voz retenía, como la madre bravía al hijo, una fuerza predestinada sobre los dolores del mundo.

Las grandes voces que se alzan sobre la tierra de tarde en tarde, por no decir de siglo en siglo, trayéndonos un resplandor ignorado que se hace fecundo en los pueblos, suelen darnos una nueva belleza o una nueva verdad o ambas cosas a la vez. Porque el arte no acaba de desbordarse sobre el tiempo, como las religiones, sino cuando ha llegado el nuevo Mesías.

Indoamérica ha engendrado la nueva voz, que ya es entraña y signo de la emoción universal. Tiene su acento y su gama, su sentido perenne, su ascensión sobrehumana. La belleza habla en los labios de esta mujer cobriza, de rostro grabado por el dolor y la ternura y por la suprema claridad del cielo. La belleza andaba perdida entre los barrancos y tinieblas, entre afanes desesperados y mortales acrobacias; y esta mujer humilde, con sus herramientas indias y su pasión, la encontró cuando su pie desnudo de niña se desgarraba entre los pedruscos de la tierra nativa. ¿No fluye ya la leyenda de su nacimiento? Pese a las noticias de los diarios, por ahí se vacila en scñalar su aldea de origen. Quien dice conocerla por haber convi- 
vido los años de niñez, afirma que nació en una aldea casi ignorada del Huasco, Fragüita, y no en Vicuña. Se habla ya de que su progenitor, maestro de primeras letras, experimentó a raíz del nacimiento de Gabriela extraño cambio en sus hábitos de vida y sólo los recobraba al hablar de su hija, a quien vaticinaba un porvenir glorioso.

En la poesía de Gabriela Mistral se amasan divinamente el dolor -el dolor de saber al mundo injusto y ciego con el humilde y necesitado-, quebrado en queja o vertido en ternura, y el amor a veces desbordado y apocalíptico. Las primeras imágenes de su niñez, conviviendo las horas de la escuela común, mísera y desolada como las escuelas rurales de hoy, alimentaron la emoción creadora todavía recogida, vacilante en los primeros versos, hasta que el amor, el gran amor, razón y destino de eternidad, precipitó aquellas fuentes donde la vida aún no está plenamente revelada. Ese temblor de la sangre y la entraña despierta hacia la embriaguez, hacia el espacio y el vértigo, se quiebra encima de la esperanza y del ansia, y luego todo es cataclismo, donde golpean la desilusión primero y luego la desgracia sin término.

No cantes; siempre queda

a tu lengua apegado

un canto: el que debió ser entregado.

No beses: siempre queda

por maldición extraña,

el beso al que no alcanzaron las entrañas.

El dolor, agigantado, se hace tierra ondulante, abismo y cumbre, y parece que el sol abrasara cordilleras y valles y la tiniebla embrujase todas las auroras. No existe el silencio, pues hay una voz que no descansa, abierta como la herida del mundo. Grito, queja, pasión, castigo, amargura; amargura en los astros, en la sangre de la tierra ilímite. 
Si yo te odiara, mi odio te daría

en las palabras rotundo y seguro;

ipero te amo y mi amor no se confía

a este hablar de los hombres tan oscuro!

Estoy lo mismo que estanque colmado

$y$ te parezco un surtidor inerte.

iTodo por mi callar atribulado

que es más atroz que entrar en la muerte!

Hay un momento en que su alma tiene resonancias de sepulcro. Todo está perdido y la voz invoca al divino hermano del Monte de los Olivos:

Ahora, Cristo, bájame los párpados,

pon en la boca escarcha,

que están de sobra ya todas las horas

y fueron dichas ya todas las palabras.

Recibeme, voy plena,

tan plena voy como tierra inundada.

Un acento grave, cósmico, de órganos soplando en la noche del mundo, sostiene esta apasionada sinfonía de la desolación. Va más allá de la simple queja humana. Es la Mujer que se ajusticia y ajusticia al dolor universal amamantado por el amor que se encendió en la primera mirada y el último beso. Es la naturaleza con sus horizontes abiertos, desencadenada; la sentencia divina y humana arrancada a las remotas edades de la Biblia y a los abismos sagrados de la India, renacida en sangre americana, en barro nativo, alucinado. Todo este Dolor se recoge y alza en Desolación.

Mas no es posible que estos odres de pasión se estrujen sin consecuencia en la fluyente vida de los días iguales. No; en el alma de esta mujer, que es virgen y mártir, tanta sangre hace un océano, 
suma de océanos y el amor se cuaja en ella en maternidad sin par, porque a su labio ha bastado el beso del hombre para que sus manos se muevan sobre la criatura acunada en lo más puro de su entraña. Así ha plasmado niño y ternura y las mujeres del planeta hablan en ella para todos los que sufren cuando oyen llorar a una criatura. Ternura que se vuelca en la choza y el palacio, sobre la tierra entera, y sirve a todas las madres que la mezquinan. Pero antes, habrá de gemir todavía su invocación martirizada:

Apacenté los hijos ajenos, colmé el troje con los trigos divinos y sólo de Ti espero. ¡Padre Nuestro que estás en los cielos! Recoge mi cabeza mendiga, si en esta noche muero.

iUn hijo, un hijo, un hijo! Yo quiero un hijo tuyo y mio allá en los días de éxtasis ardiente, en los que hasta mis huesos temblaron de tu arrullo $y$ un ancho resplandor creció sobre mi frente.

La ternura es el licor que ablanda la recia arcilla de esta maternidad desesperada. ¿Qué niño dejaría de gozarla si es ternura con dolores de parto y luz arrancada a un mundo sin pan ni regazo?

El estanque copia todo

lo que tú mirando estás;

pero tú en los ojos copias

a tu niño y nada más.

¿En dónde tejemos la ronda?

¿La haremos a orillas del mar?

El mar danzará con mil olas

haciendo una trenza de azahar. 
Genio maternal en trance de poesía deslumbrada confluye en su excelsitud de Maestra. Maestra de América para la infancia del mundo. Una sensibilidad ejercitada de modo tan hondo en la poesía y en el contacto diario de sus criaturas, ha forjado la magnitud de su apostolado, que América busca.

Ya está dicho: Gabriela es una gran voz en el tiempo. Profecía de la eterna belleza. Voz inconfundible, en consecuencia voz nueva, lengua nueva. No es propiamente la lengua castellana, aunque sus orígenes estén en ella; es la lengua criolla de esta América morena, donde los reflejos del cobre encienden la pasión, el trigo se hace leche y el salitre es siembra de resurrecciones. Gabriela lo ha dicho y esta afirmación de quien ha encontrado el universo con su palabra no podría ser siquiera discutida o callada por los fariseos del idioma. Tiene esta lengua que ya hoy alcanza jerarquía y altivez, los contactos y los pulsos vitales del medio: potencia telúrica que le ahoga fragilidades, sentido directo o intuición rauda, contornos fuertes y ricos, densidad, calor de sangre indómita. Más aún, color, color de tierra inundada de sol macho.

Esta lengua criolla ha estado creciendo, acendrándose desde el primer día, esperando su pasión, su alumbramiento cabal. Y el genio hecho mujer debía ser quien la entregara, por natural milagro. Obras maestras estaban haciendo esta forja en cada país de esta América india, mientras las viejas formas sin sangre y los snobismos pálidos se rezagaban en salones y sobremesas. Ninguna de tales obras recordaba a la Europa y todas abrían sus pulmones a los vientos de nuestra vida. Gallegos, Rivera, Güiraldes, Darío, Arguedas, Vallejos, Azuela, Robleto y tantos más, vivieron el hechizo de la sabana o de la selva, de la muchedumbre vencida e invencible, de la tierra erguida 
de los Aconcagua y los Chimborazo. Faltaba, quizás, la voz que rompiera los moldes de la Pocsía y mostrara caminos a la ternura. El momento ha llegado. Hay una lengua criolla, ya encendida en resplandores gloriosos. Bien por nuestra hermana Gabriela Mistral. Bien por los artesanos de América.

Algunos, a veces, hablan de no entender la poesía de Gabriela. Son aquellos que están habituados a lucubrar con las sombras. Esta poesía humana y solar es la negación de aquellos mundos ciegos. $\mathrm{Si}$ los niños del planeta la gozan en los labios y la danzan en sus rondas, habrán de sentirla en la sangre. Los hombres vestidos de humildad, también habrán de gozarla, como se goza el pan.

En los últimos años veíamos con angustia la errancia de su cuerpo cansado y enfermo. No era ya la inquietud de su destino superior o la voluntad de su pueblo, lo que la empujaba de un continente a otro en faena iluminadora. No, era, sin duda, el embrujo vagabundo, que ya de niño prende en los ojos del chileno y desvela sus pies. Gabriela, usando sus credenciales de Cónsul Vitalicio en país de su elección, permaneció algún tiempo en Italia y un buen día la vimos pasar a Norteamérica. Pensábamos que el corazón, ese badajo de tantas y tan asombrosas resonancias, la amenazaba y llevaba sus pies por caminos de reposo transitorio. A veces encontrábamos en sus poemas últimos y en esos íntimos "recados" para Chile, el ritmo y la sonrisa del alivio logrado. Pero lo cierto es que aquellos pies suyos, torpes en la quietud, la llevaban estoicos y humildes hacia la próxima muerte. No iban a dejarla vencida en algún olvidado sendero. Así, llegó a pedir un lecho para morir. La martirizada vagancia de los últimos años no era otra cosa que la búsqueda del buen regazo. Muere el 10 de enero de este año en el Hospital General de Hempstead, Long Island, Estados Unidos. Tenía 67 años. 
Su voz recoge todas las potencias de la vida, de la tierra y el cielo. Cantó al amor con fuerza indomeñable y desesperada. Su acento descansó a ratos en la ternura y plasmó para los niños del mundo los versos más sublimes.

La tierra de América, de la que Gabriela es brote indómito, arde $y$ crepita en su canto infinito. 